\title{
Perceptions of a Vegetarian Diet Among Students
}

\author{
Barbara JANŽIČ $\check{1}^{\text {, Vesna BUKOVAC }}$, Marjan SKALICKY ${ }^{2}$, Tadeja KRANER-ŠUMENJAK ${ }^{*}$ \\ ${ }^{1}$ University of Maribor, Faculty of Agriculture and Life Sciences, Pivola 10, 2311 Hoče, Slovenia \\ ${ }^{2}$ University of Maribor, Faculty of Medicine, Taborska ulica 8, 2000 Maribor, Slovenia
}

\begin{abstract}
A vegetarian diet may include many meat substitutes, which can mimic the taste of meat. These products can mislead or deceive many omnivorous people. The aim of the study was to find out whether the students, who were the participants, would be able to differentiate between the origins of the products (meat, vegetarian and vegan), and which types of products they would like the most, judging by taste and appearance. In separating between the origins of products, they were wrong in only one of five products (vegetarian product). The results of the sensory evaluation indicated that all samples except the vegan smoked sample were positively accepted by the students. The sensory evaluation results indicate that the students positively accepted all products except the vegan smoked sample. Therefore, the current study demonstrated that meat substitutes could be an effective way for consumers to lower their meat consumption without compromising too much of the sensory quality.
\end{abstract}

Key words: vegetarianism, meat substitutes, sensory analysis, 9-point hedonic scale

\section{INTRODUCTION}

In recent years, plant-based alternatives to conventional animal products have gained a lot of attention. Medawar et. al. (2019) have presented the positive effects of plant-based diets on physical health. In a vegetarian diet, there can be many meat substitutes which can mimic the taste of meat. These products can mislead or deceive many omnivores (Choudhury et. al., 2020). Some examples of such meat substitutes are tofu or bean curd, tempeh and seitan or wheat meat. For meat substitutes to be accepted by non-vegetarian consumers, they should fit into a meal and should most importantly have the shape and appearance of the meat substitute (Elzerman et. al., 2011). The findings of the study by Koning et.al. (2020), about drivers and inhibitors in acceptance of meat alternatives (plant and insectbased proteins) show, that there are differences in consumer attitudes and these influence behavioural intentions towards plant-based and insect-based protein as meat alternatives. Consumer's behavioural intentions towards meat alternatives are influenced by attitudes, beliefs and food neophobia (Hoek et. al., 2011; Koning et.al., 2020). Fiorentini et. al. (2020) reviewed studies which were focused on evaluating the impact of ingredients and processing methods for meat analogues and meat extenders on sensory attributes and consumer acceptance. They found out that sensory evaluation methods involving untrained and trained consumers can provide a better understanding of how different factors (such processing and ingredients) affect the quality attributes and overall consumer acceptance of meat analogues.

Sensory analysis is a scientific method of describing, evaluating and identifying foods by using senses such as taste, smell, touch and sight. Samples should not differ significantly in appearance, colour, shape, consistency or temperature. The assessors must avoid eating, drinking and smoking at least 30 minutes before the assessment (Golob et. al., 2005). An affective test or hedonic test is a method to assess the liking or disliking of a product (Lawless and Heymann, 2010). The most popular hedonic scale is the 9-point hedonic scale (scale of liking) (Peryam and Girardot, 1952). The aim is to determine the acceptability of a product among consumers. The test can

${ }^{*}$ Correspondence to:

E-mail:tadeja.kraner@um.si 
be conducted at different locations: in schools, kindergartens, colleges or within the company. At least 50-100 assessors, representing a representative sample of a defined population need to take part. The room, where sensory evaluation is conducted is called a panel room. Optimum temperatures, noise avoidance and the absence of foreign odours must be ensured. The samples must be representative and prepared in the same way (size between 5-15 g). The solid samples were served on plastic plates marked with three-digit random numbers (Golob et. al., 2006).

The purpose of this study was to find out, if students would be able to differentiate between the origins of the products (meat, vegetarian and vegan), and which sort of products they would like the most judging by taste and appearance.

\section{MATERIALS AND METHODS}

\section{Sensory evaluation of food}

Omnivorous students from the Faculty of Agriculture and Life Sciences participated (untrained assessors) in the sensory evaluation of various samples. A total of 54 students participated, of whom 22 (40.7\%) were male and $32(59.3 \%)$ were female and 33 students were at a bachelor $(61.1 \%)$ and $21(38.9 \%)$ at a master's academic level. We did not obtain the information whether the participants have had breakfast before the testing and if they smoked cigarettes.

The testing took place in the morning (between 9:00 and 13:00) in a lecture room at the Faculty of Agriculture and Life Sciences, which served as a panel/testing room. The testing room was kept at a temperature of $22^{\circ} \mathrm{C}$. Ten students participated at the same time and were separated for individual testing. Before the testing, the students were informed about the course of the tasting. They were told to examine the sample in the following order: colour and appearance, odour, texture and taste. They were familiarized with the contained allergens. In front of each student, plates with samples were arranged in a random order. The sensory evaluation was divided into two parts. In the first part of the evaluation, students did not know the origin of the products and were judging the products only by their appearance, colour and taste (9-point hedonic scale, 1 = dislike extremely; $5=$ neither like nor dislike; $9=$ like extremely), and they had to choose the product they liked the most as well. In the second part, they were informed that some products could be vegetarian or even vegan, so they had to identify the origin of individual products.

\section{Samples and their preparation}

Samples of products were purchased and selected randomly in different stores. Vegetarian samples were from the same manufacturer, vegan and chicken were from different manufacturers. They were stored in a cold place and served at room temperature. Students were offered 5 samples of different origins (Figure 1), which were marked with threedigit random numbers. Samples 233 and 584 were products of animal origin (meat) from different manufacturers

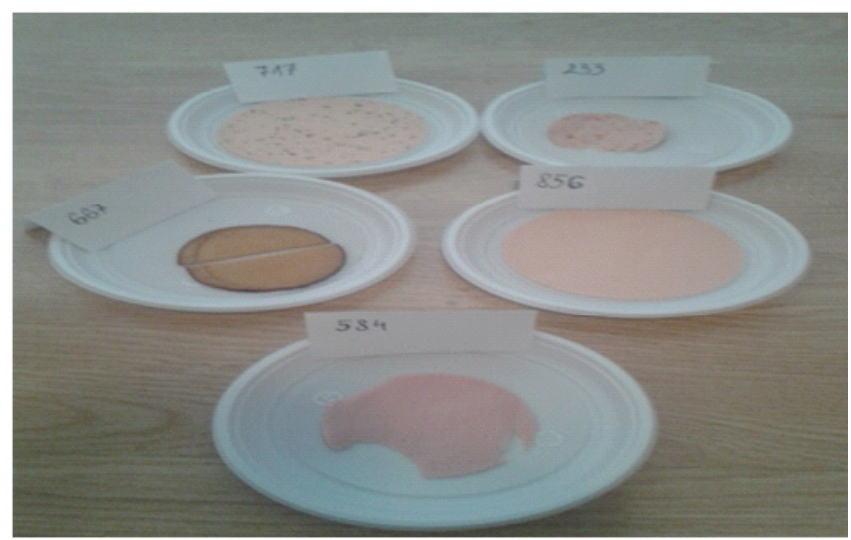

Figure1: Samples for sensory evaluation

(ingredients: chicken meat, starch, gluten, animal fats), the first sample (233) also contained herbs and peppers, while sample 584 was a plain chicken special sausage. Samples 717 and 856 were lacto-ovo vegetarian products from the same manufacturer (milk protein, pea protein, whey protein, palm fat, sunflower oil). Additionally, sample 717 contained pickled cucumbers, while sample 856 was a classic vegetarian product. Sample 667 was a smoked product (wheat protein, palm fat, sunflower fat, beetroot).

\section{Statistical analysis}

The statistical analysis was performed using the IBM SPSS Statistics 25. Descriptive statistics, Friedman analysis of variance by ranks, and the Wilcoxon test with Bonferroni correction were used to analyse the results of the sensory evaluation. For each sample we calculated the average rating $(\bar{X})$, standard deviation (s), minimum rating ( $\min )$, maximum rating (max), median $\left(\mathrm{m}_{\mathrm{e}}\right)$, first quartile $\left(\mathrm{q}_{1}\right)$, third quartile $\left(\mathrm{q}_{3}\right)$, and quartile deviation $\left(\mathrm{q}_{\mathrm{d}}\right)$. The Friedman analysis of variance by ranks is a non-parametric statistical test that is used when dealing with ordinal data for k-dependent samples. When the results of the Friedman test indicated statistically significant differences, we continued with multiple comparisons. For each data pair, we calculated the Wilcoxon signed-rank test (Sheskin, 2000), which is a non-parametric alternative to the dependent t-test for paired samples. As a result, we were dealing with a number of independent comparisons simultaneously; therefore, the probability of a Type 1 error was higher than the prescribed level $\alpha=0.05$. We calculated the adjusted alpha level of $0.05 / 10=0.005$ proposed by Bonferroni (1935).

\section{RESULTS AND DISCUSSION}

\section{Sensory evaluation of food}

The results of descriptive statistics (Table 1 and Table 2) showed that the product which stood out the most, was the smoked vegan product $\left(\bar{\chi}_{\text {taste }}=3.76\right.$ and $\left.\bar{\chi}_{\text {taste }}=3.19\right)$. The median value for the taste and colour of this sample was 3 . All other samples had a median of 7 for taste and colour, except the vegetarian product with cucumber, which had a median of 6 for colour. Since the test results were statistically 
Table 1: Descriptive statistics for taste of products involved in sensory analysis.

\begin{tabular}{|c|c|c|c|c|c|}
\hline & Chicken with herbs and peppers & Chicken & $\begin{array}{l}\text { Vegetarian with } \\
\text { cucumbers }\end{array}$ & Smoked vegan & Vegetarian \\
\hline$n$ & 54 & 54 & 54 & 54 & 54 \\
\hline $\min$ & 1 & 3 & 1 & 1 & 2 \\
\hline $\max _{9}$ & 9 & 9 & 9 & 9 & \\
\hline $\bar{\chi}$ & 6.69 & 6.74 & 6.20 & 3.76 & 6.81 \\
\hline$s$ & 1.67 & 1.78 & 2.00 & 2.26 & 1.65 \\
\hline$q_{1}$ & 6 & 6 & 5 & 2 & 6 \\
\hline$m_{e}$ & $7 \mathrm{a}$ & $7 \mathrm{a}$ & $7 \mathrm{a}$ & $3 \mathrm{~b}$ & $7 \mathrm{a}$ \\
\hline$q_{3}$ & 8 & 8 & 8 & 5.25 & 8 \\
\hline$q_{d}$ & 1 & 1 & 1.5 & 1.63 & 1 \\
\hline
\end{tabular}

a-b median values followed by different letters within a row are significantly different (Wilcoxon signed rank test with a Bonferroni correction, $\alpha=0.05$ ).

Table 2: Descriptive statistic for colour of products involved in sensory analysis.

\begin{tabular}{|l|c|c|c|c|c|}
\hline & $\begin{array}{c}\text { Chicken with herbs and } \\
\text { peppers }\end{array}$ & Chicken & $\begin{array}{c}\text { Vegetarian with } \\
\text { cucumbers }\end{array}$ & Smoked vegan & Vegetarian \\
\hline$n$ & 54 & 54 & 54 & 54 & 54 \\
\hline $\min$ & 3 & 2 & 2 & 9 & 2 \\
\hline $\max _{9}$ & 8 & 9 & 6.39 & 3.19 & 6.96 \\
\hline $\bar{\chi}$ & 6.2 & 6.19 & 1.80 & 2.16 & 1.70 \\
\hline$s$ & 1.8 & 4.75 & 5 & $3 \mathrm{~b}$ & 5.75 \\
\hline$q_{1}$ & 4 & $7 \mathrm{a}$ & $6 \mathrm{a}$ & 5 & $7 \mathrm{a}$ \\
\hline$m_{e}$ & $7 \mathrm{a}$ & 8 & 8 & 1 & 8 \\
\hline$q_{3}$ & 7 & 1.63 & 1.5 & & 2.25 \\
\hline$q_{d}$ & 1.5 & & & & \\
\hline
\end{tabular}

a-b median values followed by different letters within a row are significantly different (Wilcoxon signed rank test with a Bonferroni correction, $\alpha=0.05$ ). Legend: $n$ - assessment total, $\min$ - minimum grade, $\max$ - maximum grade, $\bar{X}$ - average grade,

$s$ - standard deviation, $q_{1}$ - first quartile, $m_{\varepsilon}$ - median, $q_{3}$ - third quartile, $q_{d}$ - quartile deviation

Table 3: Recognition of product origin.

\begin{tabular}{|c|c|c|c|c|c|c|c|c|c|c|}
\hline & \multicolumn{2}{|c|}{$\begin{array}{l}\text { Chicken with herbs } \\
\text { and peppers }\end{array}$} & \multicolumn{2}{|c|}{ Chicken } & \multicolumn{2}{|c|}{$\begin{array}{l}\text { Vegetarian with } \\
\text { cucumbers }\end{array}$} & \multicolumn{2}{|c|}{ Smoked vegan } & \multicolumn{2}{|c|}{ Vegetarian } \\
\hline & $\mathrm{f}$ & $\%$ & $\mathrm{f}$ & $\%$ & $\mathrm{f}$ & $\%$ & $\mathrm{f}$ & $\%$ & $\mathrm{f}$ & $\%$ \\
\hline Meat & 41 & 75.9 & 48 & 88.9 & 15 & 27.8 & 2 & 3.7 & 34 & 63.0 \\
\hline Vegan & 0 & 0 & 1 & 1.9 & 5 & 9.3 & 42 & 77.8 & 3 & 5.6 \\
\hline Vegetarian & 13 & 24.1 & 5 & 9.3 & 34 & 63.0 & 10 & 18.5 & 17 & 31.5 \\
\hline Total & 54 & 100.0 & 54 & 100.0 & 54 & 100.0 & 54 & 100.0 & 54 & 100.0 \\
\hline
\end{tabular}

significant ( $\mathrm{p}$-value was 0.000 ), we performed a multiple comparison test in both cases. The results pertaining to taste and colour indicate that statistically significant differences were found between the median of the vegan smoked sample and all other samples, while all other paired comparisons were not significant. Thus, all samples except the vegan smoked sample were positively accepted by the students.

The students had to determine the origin of the presented products and the results of that are shown in Table 3. Three quarters of the students $(75.9 \%)$ identified the chicken product with herbs as a meat product. Those who thought it was a vegetarian product (14.1\%) might have been distracted by the added herbs and peppers. Chicken sausage was correctly identified as a meat product by $88.9 \%$ of students. A small percentage of students (9.3\%) thought the sausage was a vegetarian product and only $1.9 \%$ decided it was a vegan product. More than half of the students (63\%) correctly identified the origin of the vegetarian cold cuts with pickled cucumbers. More than a quarter $(27.8 \%)$ thought the product was made from meat and a small percentage of students (9.3\%) decided it was a vegan product. A little over three quarters of students $(77.8 \%)$ correctly identified the smoked vegan product (667). About a fifth of students (18.5\%) thought it was a vegetarian product and $3.7 \%$ of students decided it was a meat product. The vegetarian classic cold cuts proved a hard nut to crack. More than half of the students (63\%) were 
convinced that they had tasted a meat product. Less than a third of the students $(31.5 \%)$ correctly identified the product as vegetarian. Only a few students (5.6\%) thought they had tried vegan cold cuts.

Recent studies indicate that consumers prefer meat products rather than plant-based products (Nevielle et. al., 2017; Sharima-Abdullah, 2018; Nivehta et. al., 2019). Rohall et. al. (2009) examined the consumer acceptance of four burger patties of different origins (lean beef, turkey, soy/ rice, full-fat beef). The plant-based burger patty received the highest ratings for flavour and spiciness. In a study assessing the quality and acceptance of products, Mcilveen et al. (1999) found that home-made Quorn (a vegan meat substitute) was ranked immediately behind the highest-rated domestic chicken. In a study by Neville et. al. (2017), meat, hybrid meat and meat free products were tested. Hybrid meat products (whereby a proportion of meat has been partially replaced by more sustainable protein sources) were generally well liked among consumers and there was no significant difference to the consumer acceptance of full meat products. Meat free products were, however, found to be less accepted. In a study by Sharima-Abdullah et. al. (2018) commercial chicken nuggets and an imitation of nuggets were tested, which were ICNs formulated with different percentages of chickpea flour and textured vegetable protein. The hedonic test found that consumers preferred the control nugget compared to all ICNs. Also, the results by Nivetha et. al. (2019) were similar to the results presented by Sharima-Abdullah et. al. (2018). The most acceptable was raw chicken and the least acceptable was Mushroom Panner with corn flour (T2).

\section{CONCLUSIONS}

Consumer testing has shown that the meat analogues were well accepted by omnivorous students. No significant difference in taste and colour could be seen between meat and vegetarian samples (the only exception was the vegan smoked sample). This can provide encouragement for the use of vegetarian products to reduce meat consumption and promote a vegetarian diet. Meat production already consumes most of the global arable land and is a major source of greenhouse gases. By replacing meat with meat alternatives, we could help reduce the current agricultural land use footprint from food production (Alexander et.al., 2017), but this can happen only if meat substitutes are accepted by consumers and when they know the benefits and risks of a vegetarian diet. Further research is needed to compare the parameters of internal quality and nutritional value of meat and plant meat substitutes, in order to better understand and accept the latter.

\section{REFERENCES}

1. Alexander, P., Brown, C., Arneth, A., Dias, C., Finnigan, J., Moran, D., \& Rounsevell, M. D. A. (2017). Could consumption of insects, cultured meat or imitation meat reduce global agricultural land use? Global Food Security, 15, 22-32. Retrieved from: https://doi.org/10.1016/j. gfs.2017.04.001

2. Bonferroni, C. E. (1935). II calcolo delle assicurazioni su gruppi di teste. Studi in Onore del Professore Salvatore Ortu Carboni (pp. 13-60). Italy: Rome.

3. Choudhury, D., Singh, S., Seah, J. S. H., Yeo, D. C. L., \& Tan, L. P. (2020). Commercialization of plant-based meat alternatives. Trends in Plant Science, 25(11), 1055-1058. Retrieved from: https://doi.org/10.1016/j. tplants.2020.08.006

4. Elzerman, J. E., Hoek, A. C., van Boekel, M. A. J. S., \& Luning, P. A. (2011). Consumer acceptance and appropriateness of meat substitutes in a meat context. Food Quality and Preference, 22, 233-240. Retrieved from: https://doi.org/10.1016/j.foodqual.2010.10.006

5. Fiorentini, M., Kinchla, J. A., \& Nolden, A. A. (2020). Role of sensory evaluation in consumer acceptance of plant-based meat analogs and meat extenders: A scoping review. Foods, 9, 1-15. Retrieved from: https://doi. org/10.3390/foods9091334

6. Golob, T., Bertoncelj, J., Doberšek, U., \& Jamnik, M. (2006). Senzorična analiza živil (pp. 81). Ljubljana, Biotehniška fakulteta, Oddelek za živilstvo.

7. Golob, T., Jamnik, M., Bertoncelj, J., \& Doberšek, U. (2005). Sensory analysis: Methods and assessors. Acta agriculturae Slovenica, 85(1), 55-66.

8. Hoek, A. C., Luning, P. A., Weijzen, P., Engels, W., Kok, F. J., \& de Graaf, C. (2011). Replacement of meat by meat substitutes. A survey on person- and productrelated factors in consumer acceptance. Appetite, 56(3), 662-673. Retrieved from: https://doi.org/10.1016/j. appet.2011.02.001

9. Koning, W., Dean, D., Vriesekoop, F., Aguiar, L. K., Anderson, M., Mongondry, P., Oppong-Gyamfi, M, Urbano, B., Luciano, C. A. G., Jiang, B., Hao, W., Eastwick, E., Jiang, Z., \& Boereboom, A. (2020). Drivers and Inhibitors in the acceptance of meat alternatives: The case of plant and insect-based proteins. Foods, 9(9): 1292, 1-18. Retrieved from: https://doi.org/10.3390/ foods 9091292

10. Lawless, H. T., \& Heymann, H. (2010). Sensory evaluation of food: Principles and practices. $2^{\text {nd }}$ ed. (pp 587). New York, US: Springer.

11. Mcilveen, H., Abraham, C., \& Armstrong, G. (1999). Meat avoidance and the role of replacers. Nutrition \& Food Science, 99(1), 29-36.

12. Medawar, E., Huhn, S., Villringer, A., \& Witte, V. (2019). The effects of plant-based diets on the body and the brain: a systematic review. Translational Psychiatry, 9(226), 1-17. Retrieved from: https://doi.org/10.1038/ s41398-019-0552-0

13. Neville, M., Tarrega, A., Herison, L., \& Foster, M. (2017). Consumer-orientated development of hybrid beef burger and sausage analogues. Food Science \& Nutrition, 5(4), 852-864. Retrieved from: https://doi.org/10.1002/ fsn 3.466

14. Nivetha, B. R., Sudha, K., Rita, Narayanan, \& Vimalarani, M. (2019). Development and sensory evaluation of meat analog. International Journal of Current Microbiology and Applied Sciences, 8(8), 1283-1288. Retrieved from: https://doi.org/10.3390/foods9091334

15. Peryam, D. R., \& Girardot, N. F. (1952). Advanced taste- 
test method. Food Engineering, 24(7), 58-61.

16. Rohall, S., Ballintine, J., Vowels, J., Wexler, L., \& Goto, K. (2009). Who's your patty? Consumer acceptance and sensory properties of burger patties made with different types of meat or plant- based products. American Dietetic Association, 109(9), 1-6. Retrieved from: https:// doi.org/10.32398/cjhp.v7iSI.1995

17. Sharima-Abdullah, N., Hassan, C. Z., Arifin, N., \& Huda-Faujan, N. (2018). Physicochemical properties and consumer preference of imitation chicken nuggets produced from chickpea flour and textured vegetable protein. International Food Research Journal, 25(3), 1016-1025.

18. Sheskin, D. J. (2000). Handbook of parametric and nonparametric statistical procedures (pp. 982). Boca Raton, Florida, US: Chapman \& Hall/CRC. 


\section{Poznavanje vegetarijanske prehrane med študenti}

\section{IZVLEČEK}

V vegetarijanski prehrani najdemo veliko nadomestkov mesa in mesnih izdelkov, ki posnemajo okus mesa. Ti izdelki lahko zavedejo oziroma prevarajo marsikaterega vsejedca. Zanimalo nas je, ali študentje ločijo med izvori narezkov (mesni, vegetarijanski, veganski) ter katera vrsta narezka jim je bolj všečna po okusu in videzu. Pri ločevanju izvora narezkov so se študentje zmotili le pri enem od petih izdelkov (vegetarijanskem izdelku). Rezultati senzorične analize so pokazali, da so študentje vse vzorce z izjemo veganskega dimljenega, pozitivno sprejeli. Trenutna študija je tako pokazala, da bi lahko nadomestki mesa predstavljali učinkovit način za zmanjšanje porabe mesa, ne da bi pri tem preveč ogrozili senzorično kakovost.

Ključne besede: vegetarijanstvo, nadomestki mesa, senzorična analiza , 9-stopenjska hedonska lestvica. 